
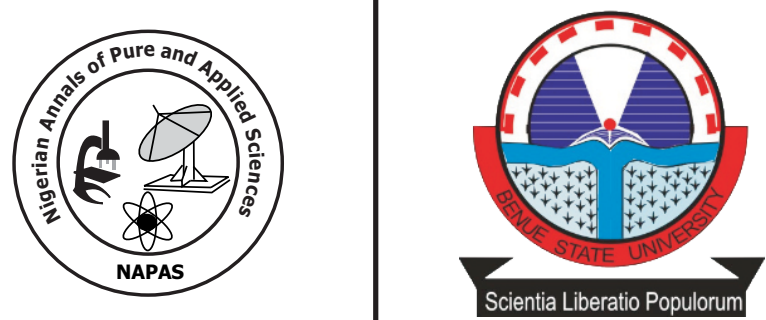

\title{
Pathogenic Bacterial Flora of Raw Chicken Eggs Sold in Jos, Plateau State, Nigeria
}

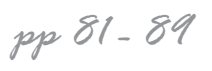

\author{
${ }^{1 *}$ Sar, T.T., ${ }^{2}$ Johnson, E. A. and ${ }^{3}$ Gberikon, M.G. \\ ${ }^{1,3}$ Department of Microbiology, \\ University of Agriculture, Makurdi, Benue State, Nigeria \\ ${ }^{2}$ Department of Biological Sciences, \\ University of Mkar, Gboko, Benue State, Nigeria \\ *Corresponding Author: terdzungwe@yahoo.com
}

\begin{abstract}
Eggs are an important component of the diets of increasing numbers of Nigerians and are used in a number of foods such as salad dressings and home-made creams. Jos, Plateau State, Nigeria is an important source of eggs consumed in Nigeria. However, most eggs in Jos are produced by subsistence poultry farmers with poor regard for hygienic practices. To determine the bacterial load and hence sanitary health quality of eggs sold and consumed, 100 eggs were randomly sampled from egg vendors in twenty locations of Jos North, Jos South and Jos East municipalities. Dilutions of egg shell washes and egg contents were cultured on Nutrient, and subcultured on McConkey agar and Xylose Lysine Desoxycholate (XLD) agar. All egg surfaces (shells) sampled had CFUs ranging between $1.0 \times 10^{6}-1.1 \times 10^{8} / \mathrm{mL}$ in Jos East, $4.3 \times 10^{5}-6.0 \times 10^{7} / \mathrm{mL}$ in Jos South and $3.4 \times$ $10^{5}-1.1 \times 10^{8} / \mathrm{mL}$ in Jos North respectively. While ANOVA and t-test showed no statistically significant differences $(p>0.05)$ in bacterial counts from within sample locations, Chi Square $\left(\chi^{2}\right)$ showed association $(\mathrm{p}<0.05)$ between bacterial counts and sample locations; Mean counts $1.06 \times 10^{9}, 1.32 \times 10^{8}$ and $5.11 \times 10^{7}$ per $\mathrm{mL}$ respectively in Jos North, Jos East and Jos South. Eggs with bacteria isolated from their contents constituted 8(8.0\%), while bacteria isolated included E. coli $65(65 \%)$, Shigella $25(25 \%)$ and Salmonella spp. $4(4 \%)$. E. coli was the only bacterium isolated from within $8(8 \%)$ the eggs. While no other bacteria were found in eggs contents, the pathogenic bacteria present on the eggs indicated that eggs could be potential sources of outbreaks of food-borne diseases. Regulations and awareness on sanitary quality of eggs are advocated to help safeguard the health of the egg consuming public from egg-borne food infections.
\end{abstract}

Key words: Pathogenic, Bacteria, Eggs, Jos, Nigeria, Sanitary quality 


\section{Introduction}

Eggs have natural chemical, physiological and physical properties that help prevent microorganisms from colonizing or multiplying in them. These help protect the eggs, freshly laid, until they are finally consumed, and include lysozyme, the shells and the various membranes of the egg (Frazier and Westhoff, 1986). For added safety, government food regulations in some countries require that eggs be carefully washed with detergents, sanitized and the egg's shell coating sprayed with a thin layer of a tasteless, odorless and harmless, natural mineral oil (FDACS, 2017; Mayo, 2020). Never-the-less, eggs are still susceptible to microbial, especially bacterial, activity, once the shell and membranes are broken (Okorie-Kanu et al., 2016). Bacteria of particular importance to eggs, and egg products include Salmonella, Staphylococcus, Pseudomonas and members of the coliform group (Salihu, et al., 2015; Moyle et al., 2016; Al Momani et al., 2018). Though the risk of getting ill from eggs is low, any food, such as the protein-rich eggs, can carry microorganisms that cause disease or spoil the food. Moreover, the nutrients that make eggs a high-quality food for humans present excellent growth conditions for bacteria (Al Momani et al., 2018).

In countries where the human food supply is closely regulated, internal contamination only rarely occurs in clean, uncracked fresh eggs. Moreover, cracked eggs are considered unsafe and their use discouraged. The safety of eggs for human consumption in such countries is enhanced by diverting chipped, broken or cracked eggs away from human food supply chain (Osei-somuah et al., 2003; FDACS, 2017).

In Nigeria, as in other parts of the world, eggs in human diet include pastries, salad dressings, cream, stews and beverages (OseiSomuah et al., 2003). When heated or properly cooked, eggs may not be a great threat to health. However, consumed raw, rare or poorly cooked, the profile of eggs as agents of food-borne infections rises significantly (Nwachukwu and Nwaki, 2018). Notwithstanding these threats, high rates of poverty, ignorance, poor regulation and malnutrition in Nigeria, make consumers to pay little attention to possible contaminations of the eggs purchased, or to the conditions of shells, and if defects are found, difficult to discard (FAO, 2010).

The high consumption of eggs and its products in Nigeria, and Jos in particular, makes it necessary to track possible causes of contamination. Proper handling and storage of eggs following collection will minimize the opportunity for bacterial contamination. However, improper washing procedures, high storage temperature and humidity will increase the incidence of bacterial contamination (Etuk et al., 2005).

This study was therefore undertaken to investigate the quantity and kinds of bacteria, especially the pathogens, associated with eggs sold in Jos, to help create awareness and draw attention of individuals and relevant public health authorities in Nigeria to the dangers of consuming eggs with disregard to their sanitary quality.

\section{Materials and Methods StudyArea}

The research was carried out in Jos metropolis, Plateau State. Jos, $\left(9^{\circ} 56^{\prime} \mathrm{N}\right.$ and $\left.8^{\circ} 53^{\prime} \mathrm{E}\right)$ is a city in Central Nigeria, with a population of about 900,000 residents based on the 2006 population census (PSICTDA, 2019). It is located on the Jos Plateau at an elevation of about 1,238 meters (4,062 feet) above sea level. It is the administrative capital of Plateau State and is divided into three administrative areas Jos North, Jos South and Jos East. According to Maduka et al. (2016), for a number of reasons, including as response to increased national protein demand, the mild climate and high profit, Jos has recently witnessed an increase in Poultry farming, as a result of which during the study, more than 80 commercial poultry farms were identified in Jos North and Jos South Local Government Areas (LGAs). However, other authors have identified over 1,300 poultry farms spread across the metropolis (Okeke-Agulu and Salihu, 2019).

\section{Samples Collection} adopted:

A three stage sampling technique was

I. the first stage included selection of three local governments in Jos metropolis, chosen by the preponderance of poultry farms as contained in the information brochure from the State Chapter of the Poultry 
Association of Nigeria (PAN).

ii. Stage two was the random selection of wards in each of the sample areas which included: Jos East - Shere Hills and Jarawan - Kogi. Jos South - Bukuru, Vom, Rayfield and Zawan. Jos North Tudun Wada, Terminus, Jenta - Adamu and Naraguta.

iii. the third stage was the random selection of two egg vendors from each of the selected wards. Five eggs were randomly purchased from each, giving a total of 100 eggs.

All samples were coded, collected into disinfected polythene bags and taken to the Bacterial Research Laboratory (BRL) at the National Veterinary Research Institute, (NVRI), Vom, Plateau State, within 6 hours of collection, for analysis.

\section{Isolation and Enumeration of Bacteria Cultures from egg shell surfaces}

All eggs with intact shells (by visual inspection and candling) were washed with a soft sterilised brush in $10 \mathrm{~mL}$ previously sterilised physiological saline. The resulting solution was serially diluted six fold. Spread plate technique was used for enumeration of bacteria as described by Collins et al. (2004). Briefly, $0.1 \mathrm{~mL}$ of the $10^{-6}$ dilution was spread on Nutrient Agar plates with L-glass-rods, and incubated at $37^{\circ} \mathrm{C}$ for 24 hours. Petri plates with growth were sub-cultured for purification and identification of bacteria.

\section{Cultures from egg contents}

The shell of each egg was washed with a soft brush and mild detergent, rinsed with distilled water, allowed to dry, disinfected with $70 \%$ ethanol and the small end carefully broken with a sterilized Scissors. Each egg was emptied into a sterile beaker and the contents thoroughly mixed with a sterile spatula. One millilitre (1 $\mathrm{mL}$ ) was withdrawn with a syringe, diluted two fold using peptone water as diluent. Briefly, 1 $\mathrm{mL}$ of egg homogenate was dispensed into $9 \mathrm{~mL}$ peptone water in a test tube, $\left(10^{-1}\right.$ dilution $) 1 \mathrm{~mL}$ withdrawn from this and dispensed into fresh 9 $\mathrm{mL}$ peptone water $\left(10^{-2}\right.$ dilution). Cultures were then made from this dilution by spread plate for enumeration of bacteria as previously described.

\section{Determination of Total Viable Counts (TVC)}

For TVC, Nutrient Agar plates having colony counts between 30 - 300 were counted using electronic colony counter and subcultured onto fresh MacConkey and Xylose Lysine Desoxycholate (XLD) agar for purification and identification. Petri plates with colony counts $<30$ were also noted and recorded.

One $\mathrm{ml}$ each of samples from the shell and content was serially diluted ten-fold in sterile physiological saline. One $\mathrm{ml}$ of each dilution was aseptically transferred into Petri dishes, each containing $10 \mathrm{ml}$ of Nutrient Agar (NA). Inoculated NA Plates were incubated at $37^{\circ} \mathrm{C}$ for 24 hours (Collins et al., 2004).

\section{Identification of Bacteria}

After incubation, the colonies of bacteria were studied for size, shape, outline, color and changes on various media. Standard microbiological, biochemical tests and microscopy, including, motility, urea utilization, indole, citrate utilization, oxidase, Voges - Proskauer (VP) tests and Gram reaction were used for identification of isolated bacteria.

\section{Statistical Analysis}

Statistical software SPSS (ver 2.0) was used to analyse collected data. One way ANOVA was used to respectively measure significant differences between bacterial counts at the Jos North and Jos South sample sites. Ttest was used to measure significant differences between bacterial counts at sample sites in Jos East, while Chi square $\left(\chi^{2}\right)$ was used to test association between bacterial counts and the three sample locations. All tests were carried out at $95 \%$ confidence level (0.05 level of significance).

\section{Results}

Table 1 shows breakdown of cultures of egg surface and content by location. All eggs had isolates from the egg shells. Bukuru in Jos South had the highest numbers of positive egg content cultures with $3(30.0 \%)$ egg contents growth rate. The lowest counts from egg contents were in Terminus, Jenta - Adamu and Shere - hills, each with 1(10\%) bacterial growth rates. Chi square showed association between bacterial counts and the sample sites $(\mathrm{p}<0.05)$ Jos North showing the stronger association. 
84 | Pathogenic Bacterial Flora of Raw Chicken Eggs Sold in Jos, Plateau State, Nigeria

Table 1: Positive Bacterial Cultures from Sample Sites

\begin{tabular}{lccc}
\hline Location & $N$ & \multicolumn{2}{c}{ Bacterial Counts } \\
Eggs Examined & $\begin{array}{c}\text { Egg Surfaces } \\
\text { No. }(\%)\end{array}$ & $\begin{array}{c}\text { Egg Contents } \\
\text { No. }(\%)\end{array}$ \\
\hline $\begin{array}{l}\text { Bukuru } \\
\text { Vom }\end{array}$ & 10 & $10(100)$ & $3(30)$ \\
Rayfield & 10 & $10(100)$ & 0 \\
Zawan & 10 & $10(100)$ & $2(20)$ \\
Terminus & 10 & $10(100)$ & 0 \\
Tudun Wada & 10 & $10(100)$ & $1(10)$ \\
Jenta Adamu & 10 & $10(100)$ & 0 \\
Naraguta & 10 & $10(100)$ & $1(10)$ \\
Jarawan Kogi & 10 & $10(100)$ & 0 \\
Shere-Hills & 10 & $10(100)$ & 0 \\
Total & 10 & $10(100)$ & $1(10)$ \\
\hline
\end{tabular}

Types and frequencies pathogenic bacteria isolated from egg samples are shown in Table 2. Escherichia coli occurred at the highest frequency of $65(65.0 \%)$ on egg surfaces and a 8
$(8.0 \%)$ occurrence from within the eggs. Salmonella spp had 4 (4.0\%) occurrence on egg surfaces, but was not isolated from eggs contents.

Table 2: Frequency of Pathogenic Bacteria From Eggs

\begin{tabular}{ccc}
\hline Bacterial & \multicolumn{2}{c}{ Frequency } \\
Isolates & Shell & Content \\
No. $(\%)$ & $8(\%)$ \\
\hline Escherichia coli & $65(65)$ & 0 \\
Shigella spp & $25(25)$ & 0 \\
Salmonella spp & $4(4)$ & 0 \\
Mixed & $6(6)$ & $\mathbf{8 ( 8 . 0 )}$ \\
Total & $\mathbf{1 0 0}(\mathbf{1 0 0})$ & \\
\hline
\end{tabular}

Table 3 summarises viable counts of bacteria from the four sample locations in Jos South. While high bacterial counts were found on most egg samples, in a few cases $<30$ CFUs were found. The highest frequency of bacterial colonies $>300$ were observed from the Bukuru area. The Lowest counts of bacteria isolated were from Bukuru. Generally however, there were no significant differences $(p>0.05)$ in bacterial counts between the four sample locations in Jos South. 
Table 3: Viable Counts of Bacteria on Egg Surfaces from Locations in Jos South

\begin{tabular}{ccccc}
\hline & \multicolumn{4}{c}{ Sample Site Location } \\
Sample & Vom & Zawan & Bukuru & Rayfield \\
ID & $A 1$ & $A 2$ & $A 3$ & $A 4$ \\
\hline$J S 01$ & $<30$ & $<30$ & $1.8 \times 10^{6}$ & $1 \times 10^{7}$ \\
$J S 02$ & $1.2 \times 10^{6}$ & $6.0 \times 10^{7}$ & $4.8 \times 10^{6}$ & $5 \times 10^{6}$ \\
$J S 03$ & $4.3 \times 10^{5}$ & $7.5 \times 10^{6}$ & $8 \times 10^{6}$ & $3.8 \times 10^{6}$ \\
$J S 04$ & $<30$ & $<30$ & $8.5 \times 10^{6}$ & $>300$ \\
$J S 05$ & $1.8 \times 10^{6}$ & $<30$ & $2.5 \times 10^{6}$ & $2.7 \times 10^{6}$ \\
$J S 06$ & $2.0 \times 10^{6}$ & $<30$ & $7.5 \times 10^{6}$ & $9.5 \times 10^{6}$ \\
$J S 07$ & $1 \times 10^{7}$ & $2.7 \times 10^{6}$ & $>300$ & $1 \times 10^{7}$ \\
$J S 08$ & $1.8 \times 10^{6}$ & $5 \times 10^{4}$ & $4.02 \times 10^{6}$ & $1 \times 10^{7}$ \\
$J S 09$ & $4.0 \times 10^{6}$ & $<30$ & $>300$ & $5.2 \times 10^{5}$ \\
$J S 10$ & $1.2 \times 10^{7}$ & $5.2 \times 10^{5}$ & $9.5 \times 10^{6}$ & $2.5 \times 10^{6}$ \\
\hline
\end{tabular}

Legend: $J S=$ Jos South; $A 1, A 2, A 3, A 4=$ Sample Site 1, 2, 3, 4

Table 4 shows TVC of bacteria from egg samples from Jos North. While no particular pattern of counts was observed, the highest mean bacterial counts were from Jenta Adamu and the lowest from Terminus. However, no significant difference in bacterial counts was found at the Jos North location ( $\mathrm{p}>0.05)$.

Table 4: Viable Counts $(\mathrm{CFU} / \mathrm{ml})$ of Bacteria on Egg Surfaces from Locations in Jos North

\begin{tabular}{ccccc}
\hline \multirow{2}{*}{$\begin{array}{c}\text { Sample } \\
\text { ID }\end{array}$} & $\begin{array}{c}\text { Tudun } \\
\text { Wada }\end{array}$ & $\begin{array}{c}\text { Sample Site Location } \\
\text { Terminus }\end{array}$ & $\begin{array}{c}\text { Jenta } \\
\text { Adamu }\end{array}$ & Naraguta \\
& $B 1$ & $B 2$ & $B 3$ & $B 4$ \\
\hline$J N 01$ & $9.10 \times 10^{6}$ & $9.0 \times 10^{6}$ & $1.10 \times 10^{8}$ & $4.50 \times 10^{7}$ \\
$J N 02$ & $1.41 \times 10^{6}$ & $>300$ & $3.30 \times 10^{9}$ & $1.60 \times 10^{5}$ \\
$J N 03$ & $>300$ & $3.01 \times 10^{6}$ & $5.20 \times 10^{5}$ & $>300$ \\
$J N 04$ & $6.0 \times 10^{6}$ & $5.0 \times 10^{5}$ & $4.10 \times 10^{8}$ & $2.40 \times 10^{6}$ \\
$J N 05$ & $1.1 \times 10^{8}$ & $4.70 \times 10^{6}$ & $3.40 \times 10^{5}$ & $6.0 \times 10^{6}$ \\
$J N 06$ & $6.1 \times 10^{7}$ & $1.20 \times 10^{6}$ & $>300$ & $>300$ \\
$J N 07$ & $>300$ & $6.60 \times 10^{6}$ & $5.0 \times 10^{6}$ & $<30$ \\
$J N 08$ & $<30$ & $6.50 \times 10^{5}$ & $5.0 \times 10^{6}$ & $6.50 \times 10^{6}$ \\
$J N 09$ & $8.50 \times 10^{6}$ & $7.30 \times 10^{6}$ & $1.10 \times 10^{8}$ & $>300$ \\
$J N 10$ & $3.70 \times 10^{5}$ & $7.60 \times 10^{6}$ & $<30$ & $>300$ \\
\hline
\end{tabular}

Legend: $J N=$ Jos North; $B 1, B 2, B 3, B 4=$ Sample Sites 1, 2, 3, 4

The viable counts of bacteria from the four locations of Jos East Local Government sampling area are shown. While sample JE06 from Shere-Hills $(C 1)$ had the highest counts of bacteria per $\mathrm{ml}$, the highest mean bacterial counts was from Jawaran-Kogi. $\mathrm{T}$ - test however showed no significant differences, $(p>0.05)$ between bacterial counts at the two locations of Jos East (Table 5). 
Table 5: Viable Counts $(C F U / m l)$ of Bacteria on Egg Surfaces from Jos East

\begin{tabular}{ccc}
\hline & \multicolumn{2}{c}{ Sample Site Location } \\
Sample & Shere Hills & \\
ID & $C 1$ & Jawaran Kogi \\
\hline$J E 01$ & $4.7 \times 10^{6}$ & $1.0 \times 10^{6}$ \\
$J E 02$ & $4.1 \times 10^{5}$ & $1.23 \times 10^{6}$ \\
$J E 03$ & $2.5 \times 10^{5}$ & $8.0 \times 10^{5}$ \\
$J E 04$ & $2.6 \times 10^{7}$ & $1.21 \times 10^{7}$ \\
$J E 05$ & $<30$ & $1.52 \times 10^{6}$ \\
$J E 06$ & $7.5 \times 10^{6}$ & $3.9 \times 10^{6}$ \\
$J E 07$ & $4.4 \times 10^{5}$ & $3.03 \times 10^{7}$ \\
$J E 08$ & $<30$ & $<30$ \\
$J E 09$ & $2.81 \times 10^{7}$ & $7.4 \times 10^{5}$ \\
$J E 10$ & $>300$ & $1.1 \times 10^{8}$ \\
\hline
\end{tabular}

Legend: $J E=$ Jos East; $C 1, C 2=$ Sample Sites 1, 2

Table 6 is a summary of the bacterial load (CFUs) of egg contents from the various sample locations. From the total of 20 sample locations, $8(40 \%)$ had positive cultures from egg contents, however, 7 (35\%) out of these had less than $30 \mathrm{CFU} / \mathrm{ml}$.

Table 6: Counts of Bacteria from Eggs Content from Sample Locations

\begin{tabular}{|c|c|c|c|c|c|c|c|c|}
\hline \multirow[t]{2}{*}{$\begin{array}{l}\text { Sample Site } \\
\text { Location }\end{array}$} & \multicolumn{8}{|c|}{$\begin{array}{c}\text { Sample ID } \\
\text { Bacterial Counts }\end{array}$} \\
\hline & $J N 01$ & JS03 & JN05 & $J S 10$ & $J E 10$ & JS04 & JS06 & $J N 10$ \\
\hline Bukuru & - & - & - & - & - & $<30$ & - & - \\
\hline $\begin{array}{l}\text { Jenta- } \\
\text { Adamu }\end{array}$ & - & - & $<30$ & - & - & - & - & - \\
\hline Rayfield & - & - & - & - & - & - & $<30$ & - \\
\hline $\begin{array}{l}\text { Shere- } \\
\text { Hills }\end{array}$ & - & - & - & - & $<30$ & - & - & - \\
\hline Terminus & $<30$ & - & - & - & - & - & - & $<30$ \\
\hline Zawan & - & $9 \times 10^{2}$ & - & $<30$ & - & - & - & \\
\hline
\end{tabular}

Legend: $J N 01=$ Jos North Sample 1; JS03 = Jos South Sample 3; JN05 = Jos North Sample 5; $J S 10=$ Jos South Sample 10; JE10 = Jos East Sample 10; JS04 = Jos South Sample 4; $J S 06=$ Jos South Sample 6; JN10 = Jos North Sample 10

\section{Discussion}

The bacterial flora, especially pathogens, such as E. coli, species of Shigella and Salmonella, found on the eggs could be attributed to poor sanitary practices and handling of the eggs from the farms to the markets. It was observed that some egg samples still had dried and caked poultry droppings on them. Such poor sanitary practices by the farmers and vendors allows some of these bacteria from chickens and poultry farms onto eggs. Most farms in the sample area, probably due to the expense of purchasing battery cages, practice the deep litter system of raising birds. Even when cleaned out regularly, this system encourages spread of bacteria and other microorganisms, droppings from the birds accumulate (Etuk et al., 2004; Olayemi and Adetunji, 2013).

While bacteria were isolated at all sites from all eggs sampled, at higher levels from some sites than others, this variation was certainly not the result of superior sanitary conditions of areas with lower counts, but 
possibly simply a fortuitous occurrence, especially as none of the sites or locations sampled had in place special egg sanitary procedures. That Jos North showed stronger association with bacterial isolates could be indicative of the general sanitary state of the sample locations. These areas of Jos North metropolis generally have low levels of sanitation. It is therefore no surprise that higher levels of bacteria resulted from eggs at these locations.

Perhaps more important than bacteria isolated from shells, were the isolates from egg contents. In this regard, only E. coli was isolated. Jones et al. (2004) showed that enterobacteriaceae like Salmonella enteritidis survived better, outcompeting P. fluorescens on artificially inoculated egg.

In this study, E. coli was found to be more resilient on egg surfaces, and was probably isolated from the egg contents due to their large numbers, long survival periods and frequency on shells, which made them more likely to penetrate into the white and yolks. Also, E. coli are common bacterial flora of the gastrointestinal tracts of mammals and birds, such as the hen, migrate to the reproductive system, and are known to penetrate into eggs through the shell. Therefore E. coli could have contaminated the egg contents from the laying birds (Etuk et al., 2004; Okorie-Kanu et al., 2016).

Also, Eke et al. 2013 state that as eggs age, the bacterial growth retarding egg white thins, the yolk membrane weakens, which make it possible for bacteria to access the nutrientdense yolk, where they can grow. While investigation was not carried out into the length or period of storage of the eggs by the vendors, it is possible that this could have been one factor at play in the colonisation of the egg contents by bacteria.

The relatively lower levels and frequency of bacteria isolated from the eggs contents do not lessen the importance of this observation. This is because egg contents are ordinarily sterile. Therefore, any bacterial isolate from is a source of concern and worry.

The bacteria isolated from this study pose particular health risks to consumers of this food. Strains of E. coli, for example, are implicated as the cause of cholecystitis, bacteremia, cholangitis, traveller's diarrhoea amongst others in man (Davis, 2019). Shigella is the cause of shigellosis in man, while Salmonella, may not make carrier birds ill, if they get into the human food chain, can cause severe ill health ranging from typhoid fever to gastroenteritis (Brazier, 2020, CDC, 2019). When eggs are consumed rare or raw, poor egg sanitary practices such as observed during handling of the eggs, may make individuals contract these enteric diseases.

The egg shells could have become contaminated by deposition of feacal material on them, from the ovarium, oviduct, gut microflora, previously contaminated egg crates, clothes, hands of poultry workers, dust from the environment, transportation and marketing, or during storage. When eggs are not refrigerated during storage, as observed in this study, conditions are enhanced for bacterial colonisation and growth (De Reu et al., 2006). Contamination could have also resulted from feed, as bacteria, such as Salmonella spp. have been documented to be transmissible to chickens, and then to eggs, through feed (Yang etal., 2017).

The observation that eggs were contaminated with faecal matter may be because retailers and poultry farmers in the study location have yet to embrace the washing and sanitizing eggs before marketing, as they probably fear economic loss due to eggs becoming cracked or broken during this process, being manual in nature. Further, the industrial machinery for this may be out of reach of most poultry farmers, who are mostly subsistent (Okeke-Agulu and Salihu, 2019).

Egg vendors at the sample sites did not have any special equipment for storage, which were displayed in the open. As eggs were not refrigerated, which help retard and reduce bacterial growth, the spread of bacteria on and within the eggs was therefore increased (FDA, 2017).

\section{Conclusion}

Eggs sold at commercial outlets in Jos, Plateau State have been shown to have bacterial contaminants to varying degrees, both on the shells and from the contents. It has also been shown that the vendors of eggs have poor egg sanitary practices and habits. The isolated bacteria can cause illness if allowed on eggs with little or no form of control, such as 
washing.

It is recommended that eggs regulatory and other sanitary standards, such as thorough sanitizing and washing of eggs and hands by handlers of eggs, should be set and awareness on the necessary requirements to achieve these standards put in place, as these will go a long way in reducing the prevalence of contaminating microorganisms on eggs.

\section{References}

Al Momani, W., Janakat, S. and Khatatbeh, M. (2018). Bacterial Contamination of Table Eggs Sold in Jordanian Markets. Pakistan Journal of Nutrition, 17: 15 20. https://scialert.net/abstract/?doi $=$ pjn.2018.15.20 Accessed 11th May, 2020

Brazier, Y. (2020) All You Need To Know About Salmonella. MedicalNews Today https://www.medicalnewstoday.com/art icles/160942 Accessed 12th May, 2020

Centers for Disease Control and Prevention (CDC) (2019). Shigella - Shigellosis https://www.cdc.gov/shigella/generalinformation.html Accessed 14th May, 2020

Collins, C.H., Lyne, P.M., Grange, J.M. and Falkinham, J.O. III (2004) Collins and Lyne's Microbiological Methods, 8th edition, Arnold, London. 465 pp. https://mmstcchemistry.weebly.com/up loads/2/4/1/2/24121933/microbiologica 1 methods.pdf.

Davis, C. P. (2019). E. coli 0157: H7 Infection Early Symptoms, Treatment and Prevention Medicine $\mathrm{Net}$ https://www.medicinenet.com/e_coli 0157h7/article.htm Accessed 14th May, 2020

De Reu, K., Grijspeerdt, K. Messens, W. Heyndrickw, M. Uyttendaele, M. Debevere, J. and Herman, L. (2006). Eggshell factors influencing eggshell penetration and whole egg contamination by different bacteria, including Salmonella Enteritidis. International Journal for Food Microbiology 112: 253-260.

Eke, M. O., Olaitan, N. I. and Ochefu, J. H. (2013). Effects of Storage Conditions on the Quality Attributes of Shell (Table) Eggs. Nigerian Food Journal 31(2): $18-$
24 https://www.sciencedirect.com/sci ence/article/pii/S0189724115300722

Etuk, E.B., Okoli, I.C. and Uko, M.U. ( 2004). Prevalence and management issues associated with poultry coccidiosis in Abak agricultural zone, Akwa Ibom state, Nigeria International Journal of Poultry Science 3:135-139 http://docsdrive.com/pdfs/ansinet/ijps/ 2004/135-139.pdf Accessed 12th May, 2020

Etuk, E.B., Okoli, I.C. and Udedibe, A.B.I.( 2005). Priority issues in tropical animal health management. Animal Production Research Advanced. 1:83-92.

Florida Department of Agriculture and Consumer Services Division of Food Safety (FDACS) (2017) Shell Egg Processor Requirements https://www. fdacs.gov/content/download/64358/file / S H E L L - E G G - P R O C E S S O R REQUIREMENTS.pdf Accessed 11th May, 2020

Food and Agriculture Organization of The United Nations (2010) Nigeria Consultative Mission on Assessment of the Nigerian Poultry Market Chain to Improve Biosecurity http://www.fao. org/3/a-ak778e.pdf Accessed 11th May, 2020

Frazier, W. C. and Westhoff, D. C. (1986) Food Microbiology, TMH Edition, New York. 540pp.

Jones, D.R., Curtis, P.A., Anderson, K.E. and Jones, F.T. (2004). Microbial contamination in inoculated shell eggs: II. Effects of layer strain and egg storage. Poultry Science. 83(1): 95-100. https://www.ncbi.nlm.nih.gov/pubmed/ 14761090

Maduka, C. V., Igbokwe, I. O. and Atsanda, N. N. (2016) Appraisal of Chicken Production with Associated Biosecurity Practices in Commercial Poultry Farms Located in Jos, Nigeria Hindawi Scientifica 2016 https://www.hindawi.com/journals/scie ntifica/2016/1914692/ Accessed 01/06/2020

Mayo, D. (2017) What are the Requirements to Sell Eggs and Dressed Poultry from F 1 or id a S m a 11 F a r m s ? https://nwdistrict.ifas.ufl.edu/phag/201 
7/05/25/what-are-the-requirements-tosell-eggs-and-dressed-poultry-fromflorida-small-farms/ Accessed 11th May, 2020

Moyle, T., Drake, K., Gole, V., Chousalkar, K. and Hazel, S. (2016). Bacterial contamination of eggs and behaviour of poultry flocks in the free range environment Comparative Immunology, Microbiology and Infectious Diseases (49); 88-94 https://doi.org/10.1016/j. cimid.2016.10.005Get rights and content Accessed 11th May, 2020

Nwachukwu, E. and Nwaki, J. (2018) Extent of pathogenic bacterial contamination of egg rolls sold by hawkers in Delta State, Nigeria. Journal of Bacteriology and Mycology: Open Access 6(2): 127 - 128 http://medcraveonline.com/JBMOA/JB MOA-06-00189.pdf Accessed $1 / 06 / 2020$

Okeke-Agulu, K. I. and Salihu, B. I. (2019) Poultry Farmers' Participation in Agricultural Insurance in Jos Metropolis of Plateau State, Nigeria IOSR Journal of Agriculture and Veterinary Science 12(9): $21-25$ https://www.iosrjournals . org/iosr-javs/papers/Vol12issue9/Series-2/E1209022125.pdf Accessed 01/06/2020

Okorie-Kanu, O. J., Ezenduka, E. V., OkorieKanu, C. O., Ugwu, L. C. and Nnamani, U. J. (2016) Occurrence and antimicrobial resistance of pathogenic Escherichia coli and Salmonella spp. in retail raw table eggs sold for human consumption in Enugu state, Nigeria.
Veterinary World 9(11): 1312 - 1319 https:/www.ncbi.nlm.nih.gov/pmc/arti cles/PMC5146316/Accessed 1/06/2020

Olayemi, F. and Adetunji, C., (2013) Effect of rinses on microbial quality of commercially available eggs and its components before processing from Ilorin in western Nigeria Bitlis Eren University Journal of Science and Technology 3(2): 44-47

Osei - Somuah, A., Otsyina, H. R., Arthur, C.T., Nortey, P.W.K. and Hammond, V. (2003) Microbial Quality of Table eggs sold in selected markets in Accra. Animal research institute 2006. Ghana Veterinary Medical Association BiAnnual Newsletter 6(3):14-18.

Plateau State ICT Development Agency (PSICTDA) (2019) At A Glance Plateau State https://www.plateaustate .gov.ng/plateau/at-a-glance Accessed 12th May, 2020

Salihu, M. D., Garba, B., Isah, Y. (2015) Evaluation of microbial contents of table eggs at retail outlets in Sokoto metropolis, Nigeria. Sokoto Journal of Veterinary Sciences (13): $22-28$

Yang, Y., Ricke, S. C., Tellez, G. and Min Kwon, Y. (2017) Quantitative Tracking of Salmonella enteritidis Transmission Routes Using Bar-Code Tagged Isogenic Strains in Chickens: Proof-ofConcept Study. Frontiers in Veterinary Science https://www.frontiersin.org/ articles/10.3389/fvets.2017.00015/full Accessed 12th May, 2020 